\title{
Inhibition of basal and stimulated progesterone synthesis by dichlorodiphenyldichloroethylene and methoxychlor in a stable pig granulosa cell line
}

\author{
N. K. Crellin ${ }^{1}$, H. G. Kang ${ }^{2}$, C. L. Swan ${ }^{3}$ and P. J. Chedrese ${ }^{3 *}$ \\ ${ }^{1}$ Toxicology Centre, University of Saskatchewan, Saskatoon SK, Canada S7N 5B3; \\ ${ }^{2}$ National Veterinary Research and Quarantine Service, Kyung-Gi province, Republic of \\ Korea; and ${ }^{3}$ Reproductive Biology Research Unit, Department of Obstetrics, Gynecology \\ and Reproductive Sciences, University of Saskatchewan, Saskatoon SK, Canada S7N OW8
}

The effects of the insecticide dichlorodiphenyldichloroethylene (DDE) and methoxychlor in a stable pig granulosa cell line, JC-410, were investigated. The studies of DDE and methoxychlor were conducted in combination with studies of cholera toxin, the protein kinase A activator that stimulates CAMP and progesterone synthesis and gene expression of $\mathbf{P 4 5 0}$ cholesterol side chain cleavage (P450scc), which converts cholesterol to pregnenolone. Administration of DDE at 3000 and $10000 \mathrm{ng} \mathrm{ml}^{-1}$ was found to decrease progesterone synthesis 0.49 - and 0.25 fold, respectively, and to block the stimulatory effect of $100 \mathrm{ng}$ cholera toxin $\mathrm{ml}^{-1}$, after $24 \mathrm{~h}$ incubation. At 1-100 ng ml-1, methoxychlor did not affect progesterone synthesis after $48 \mathrm{~h}$ incubation. However, $1000 \mathrm{ng}$ methoxychlor $\mathrm{ml}^{-1}$ decreased progesterone synthesis 0.32-fold, and both 100 and 1000 ng methoxychlor $\mathrm{ml}^{-1}$ blocked the stimulatory effect of cholera toxin. At 3000 and $10000 \mathrm{ng} \mathrm{ml}^{-1}$, DDE decreased cAMP synthesis 0.66and 0.36 -fold, respectively. At 300, 3000 and $10000 \mathrm{ng}$ $\mathrm{ml}^{-1}$, DDE also decreased cholera toxin-stimulated cAMP synthesis 0.84-, 0.68-, and 0.52-fold, respectively. Administration of 1-100 $\mathrm{ng}$ methoxychlor $\mathrm{ml}^{-1}$ did not affect basal or cholera toxin-stimulated cAMP synthesis. Cholera toxin increased P450scc mRNA 1.4-fold after $24 \mathrm{~h}$ incubation, while 3000 and $10000 \mathrm{ng}$ DDE ml-1 led to 0.39 - and 0.18 -fold reductions, respectively. The stimulatory effect of cholera toxin on P450scc mRNA was blocked by 3000 and $10000 \mathrm{ng}$ DDE $\mathrm{ml}^{-1}$. Cholera toxin increased P450scc mRNA 3.48-fold after $48 \mathrm{~h}$ incubation, while 100 and $1000 \mathrm{ng}$ methoxychlor $\mathrm{ml}^{-1}$ increased P450scc mRNA 1.79- and 3.0-fold, respectively, and further increased the stimulatory effect of cholera toxin 6.47- and 5.44-fold, respectively. The results of the present study indicate that DDE inhibits granulosa cell steroidogenesis by affecting cAMP production and P450scc gene expression. However, methoxychlor appears to inhibit steroidogenesis by a mechanism occurring before the conversion of cholesterol into pregnenolone.

\section{Introduction}

Dichlorodiphenyltrichloroethane (DDT) is an insecticide that has been widely used around the world since the 1940s. By the early 1970s, it was discovered that intensive use of DDT resulted in bioaccumulation in the food chain and toxicity to wildlife, and as a result DDT was banned in the USA, Canada and several European countries. Nevertheless, DDT is still used extensively in other parts of the world as it is a very efficient and economic method for controlling malaria vectors and a variety of other insects that affect human health and agriculture (Lopez-Carrillo et al., 1997; Rivero-Rodriguez et al., 1997). Consequently, DDT and its most stable metabolite, $p, p$-dichlorodiphenyldichloroethylene (DDE), are continuously entering the

*Correspondence and reprint requests.

Email: chedresj@duke.usask.ca environment. These compounds have a tendency to concentrate in cold regions and have been found contaminating humans and wildlife in the Arctic regions and many other parts of the world (Ayotte et al., 1995). In humans, DDE has been detected in blood, adipose tissue (Morgan and Roan, 1971) and ovarian follicular fluid (Jarrell et al., 1993).

One of the most notable features of DDE is its ability to alter endocrine functions, resulting in its classification as an endocrine disrupter. Endocrine disruption by DDE was described in alligators exposed to a spill containing pesticides and other contaminants. The high concentrations of DDE found in the spill were believed to be responsible for altering steroid hormone concentrations and inducing phenotype abnormalities in alligators (Guillette Jr. et al., 1995, 1996). These observations raised concerns about the long-term effect of DDE on human health. The presence of the pesticide in follicular fluid means that the oocyte and the granulosa cells that 
surround the oocyte are exposed to a potent endocrine disrupter during crucial stages of development and differentiation (Jarrell et al., 1993). Thus, DDE might affect the viability of the oocyte and the endocrinology of the ovulatory follicle, with deleterious consequences for embryo health and the pregnancy. Low concentrations of DDE, similar to those that have been reported in the follicular fluid of women, may alter progesterone synthesis in granulosa cells (Crellin et al., 1999), indicating that DDE affects ovarian function by altering steroid hormone synthesis.

Methoxychlor, a more labile and readily degradable compound, has been used to replace the banned DDT. However, methoxychlor is also an endocrine disrupter with anti-fertility effects described in a number of experimental models. In rats, treatment with methoxychlor induced a decrease in serum progesterone and impaired embryo implantation (Cummings and Laskey, 1993). Methoxychlor also induced abnormal oestrus in mice after neonatal exposure and caused a number of oestrogenic effects, including vaginal cornification and increased uterine mass (Eroschenko, 1991; Eroschenko et al., 1995). In amphibians, methoxychlor inhibited progesteroneinduced oocyte maturation (Pickford and Morris, 1999). Although methoxychlor does not persist in the environment, its continuous use exposes people and animals directly to amounts that have biological effects.

Collectively, this information indicates that both DDE and methoxychlor are potent endocrine disrupters, with the potential to affect human and animal reproduction adversely. The present investigation is a detailed study on the effects of DDE and methoxychlor on a stable steroidogenic pig granulosa cell model, JC-410, developed in our laboratory and validated for toxicological studies (Chedrese et al., 1998; Crellin et al., 1999). In this study, information is provided on the mechanisms by which DDE and methoxychlor affect ovarian steroidogenesis.

\section{Materials and Methods}

\section{Reagents}

Media M199, trypsin, penicillin, streptomycin and newborn calf serum were purchased from Gibco (Burlington, ON). Glutamine, cholera toxin, insulin, cAMP and materials for CAMP acetylation and purification, and 3-isobutyl-1-methyl-xanthine (IBMX) were purchased from Sigma (St Louis, MO). Plastic culture plates were purchased from Falcon (Lincoln Park, NJ). lodinated progesterone (11- $\alpha$-hydroxyprogesterone-11- $\beta$-D-glucuronide-[ $\left.{ }^{125} \mathrm{I}\right]$-iodotriamine) was purchased from Amersham Pharmacia Biotech (Piscataway, NJ). The Bio-Rad DC protein assay kit was purchased from Bio-Rad Laboratories (Hercules, CA). The DDE used in this study was purchased from ChemService (West Chester, PA) as pure $p, p$-DDE and $o, p$-DDE. The two DDE isoforms were combined so that the final preparation would contain $96 \% p, p$-DDE and
$4 \% o, p$-DDE, dissolved in ethanol. These isoforms were mixed to represent environmental exposure. Methoxychlor $(99.0 \%)$ (PolyScience Niles, IL) was dissolved in benzene as a $1 \%$ solution.

\section{Cell cultures}

Cells were grown in phenol red-free media 199 supplemented with $5 \%$ new born calf serum, $5 \mu \mathrm{g}$ insulin $\mathrm{ml}^{-1}, 100 \mathrm{iu}$ penicillin $\mathrm{ml}^{-1}, 100 \mu \mathrm{g}$ streptomycin $\mathrm{ml}^{-1}$, 2.2 g sodium bicarbonate $\mathrm{I}^{-1}$ and 4 mmol glutamine $\mathrm{I}^{-1}$. Cultures were maintained in an incubator (Forma Scientific Inc., Marietta, $\mathrm{OH}$ ) at $37^{\circ} \mathrm{C}$ in a water-saturated atmosphere of $5 \% \mathrm{CO}_{2}$ and $95 \%$ air. Experiments were carried out in 24-well culture plates. Once 70\% confluency was attained, media were replaced with serum-free media containing the treatments. Times of exposure to DDE and methoxychlor, 24 and $48 \mathrm{~h}$ respectively, were determined in preliminary experiments. Vehicle for the DDE experiments consisted of $0.5 \%$ ethanol. The vehicle control for the methoxychlor experiments consisted of benzene in ethanol, at $0.01 \%$ benzene and $0.49 \%$ ethanol. Percentages given are $\mathrm{v} / \mathrm{v}$.

\section{Quantification of progesterone, cAMP and cellular protein}

Progesterone content was determined by radioimmunoassay in $100 \mu \mathrm{l}$ culture medium, as previously described by Chedrese et al. (1998). The inter- and intra-assay coefficients of variation for the progesterone assay were $<10 \%$, and the minimum detectable content was $6.25 \mathrm{pg}$. Generation of cAMP was tested in cells exposed to the control medium or $100 \mathrm{ng}$ cholera toxin $\mathrm{ml}^{-1}$ in the presence of the phosphodiesterase inhibitor IBMX $\left(125 \mathrm{mmol}^{-1}\right)$ for $30 \mathrm{~min}$. Cellular cAMP was extracted with $100 \mu \mathrm{l} 1 \mathrm{~mol} \mathrm{HCl} \mathrm{I}^{-1}$ for $5 \mathrm{~min}$ and diluted with

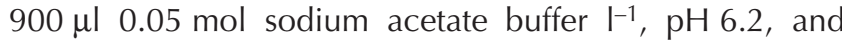
quantified by radioimmunoassay (Chedrese et al., 1998). The inter- and intra-assay coefficients of variation for the cAMP assay were $<15 \%$ and the minimum detectable content was $3.25 \mathrm{fmol}$. For protein content determination, cells were washed extensively with PBS and then solubilized with $200 \mu \mathrm{l} 0.1 \%$ SDS. Protein content was determined using the Bio-Rad DC protein kit.

\section{Northern blot analyses}

Total RNA was isolated by acid phenol:chloroform extraction according to the method described by Chomczynski and Sacchi (1987). Samples of total RNA were denatured, size-fractionated by electrophoresis on a $1 \%$ agarose-formaldehyde gel and transferred onto a nylon membrane by diffusion blotting. Pig P450scc (Mulheron et al., 1989) and glyceraldehyde-3-phosphate dehydrogenase (GAPDH) (Tso et al., 1985) cDNAs were used as probes. Probes were labelled by primer extension (Feinberg and Vogelstein, 1983) with $\left[\alpha^{-32} \mathrm{P}\right] \mathrm{dCTP}\left(>3000 \mathrm{Ci} \mathrm{mmol}^{-1}\right.$; 


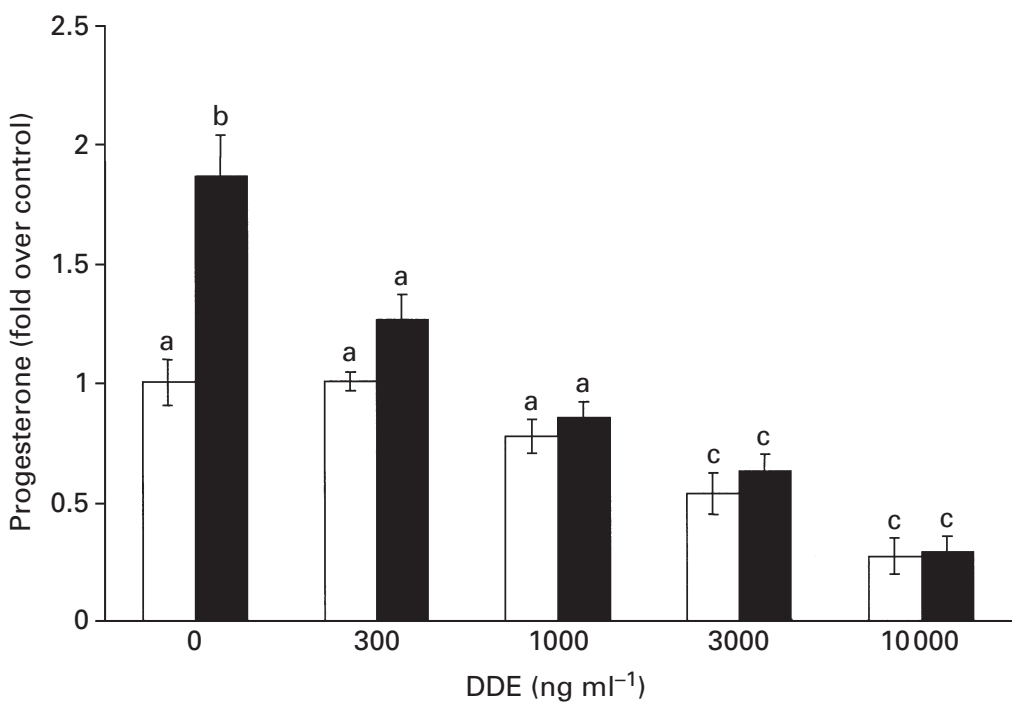

Fig. 1. Effect of dichlorodiphenyldichloroethylene (DDE) on cholera toxinstimulated progesterone synthesis. Cells were cultured with 300-10000 ng DDE $\mathrm{ml}^{-1}$ and with or without $100 \mathrm{ng}$ cholera toxin $\mathrm{ml}^{-1}$. After $24 \mathrm{~h}$ incubation, culture media and cells were collected for progesterone and protein assays, respectively. Data are the mean \pm SEM of three independent replications, expressed as fold values versus control (2.6 $\mathrm{pg} \mathrm{\mu g}^{-1}$ protein). $\square, D D E ; \quad \mathbf{\square}, \mathrm{DDE}+$ cholera toxin. Values with different letters are significantly different $(P<0.05)$.

New England Nuclear, Boston, MA) to a specific activity of 1.5-3.0 $\times 10^{9}$ d.p.m. $\mathrm{mg}^{-1}$ DNA. Membranes were hybridized and autoradiography was performed as described by Chedrese et al. (1990), using the QuikHyb hybridization solution (Stratagene, La Jolla, CA). A Kodak Electrophoresis Documentation and Analysis System 120 was used for gel photography and densitometric analysis of autoradiographs. Each experiment was repeated three times.

\section{Statistical analysis}

Data are presented as the mean \pm SEM of at least three independent experiments and were analysed using a twoway ANOVA (Figs $1-5$ ). When a significant $F$ value was present, Fisher's least significant difference test was used for individual comparison of means (Steel and Torrie, 1980). Significant differences, indicated by different letters, were defined as $P<0.05$. Fold values were calculated by dividing all data by the mean of the control group.

\section{Results}

Progesterone synthesis was increased 1.7 -fold by $100 \mathrm{ng}$ cholera toxin $\mathrm{ml}^{-1}$ and decreased 0.49 - and 0.25 -fold by 3000 and $10000 \mathrm{ng}$ DDE ml-1, respectively, after $24 \mathrm{~h}$ incubation. The stimulatory effect of cholera toxin on progesterone synthesis was blocked by 300-10 000 ng DDE ml-1 (Fig. 1). Progesterone synthesis was not affected by methoxychlor at concentrations ranging from 1 to 100 ng $\mathrm{ml}^{-1}$, after $48 \mathrm{~h}$ incubation. However, a higher concentration of methoxychlor, $1000 \mathrm{ng} \mathrm{ml}^{-1}$, decreased progesterone synthesis 0.32 -fold. The cholera toxinstimulated progesterone synthesis was blocked by 100 and $1000 \mathrm{ng}$ methoxychlor $\mathrm{ml}^{-1}$ (Fig. 2).

Synthesis of cAMP was stimulated 7.2-fold by $100 \mathrm{ng}$ cholera toxin $\mathrm{ml}^{-1}$. Conversely, 3000 and $10000 \mathrm{ng}$ DDE $\mathrm{ml}^{-1}$ decreased cAMP synthesis 0.66- and 0.36-fold, respectively. At 300, 3000, and $10000 \mathrm{ng} \mathrm{ml}^{-1}$ DDE also decreased the cholera toxin-stimulated cAMP synthesis 0.84-, 0.68- and 0.52-fold, respectively (Fig. 3). At 1-100 $\mathrm{ng} \mathrm{ml}^{-1}$ methoxychlor did not affect basal or cholera toxinstimulated cAMP synthesis (Fig. 4).

Protein concentrations were not altered by $100 \mathrm{ng}$ cholera toxin $\mathrm{ml}^{-1}$ or 300 and $1000 \mathrm{ng}$ DDE ml-1. However, at both the 3000 and $10000 \mathrm{ng}$ DDE ml-1, protein concentrations were increased 1.35- and 1.42fold, respectively, in either the presence or absence of cholera toxin (Fig. 5). Protein concentration, which correlates with the number of cells, was not altered by 1-100 ng methoxychlor $\mathrm{ml}^{-1}$, in the presence or absence of cholera toxin (data not shown).

P450scc mRNA was increased 1.4-fold by $100 \mathrm{ng}$ cholera toxin $\mathrm{ml}^{-1}$ after $24 \mathrm{~h}$ incubation, while 3000 and 10000 ng DDE ml-1 decreased P450scc mRNA to 0.39and 0.18 -fold, respectively. The cholera toxin-stimulated amounts of P450scc mRNA were blocked by 3000 and 10000 ng DDE ml-1 (Fig. 6). At 100 ng cholera toxin $\mathrm{ml}^{-1}$, 


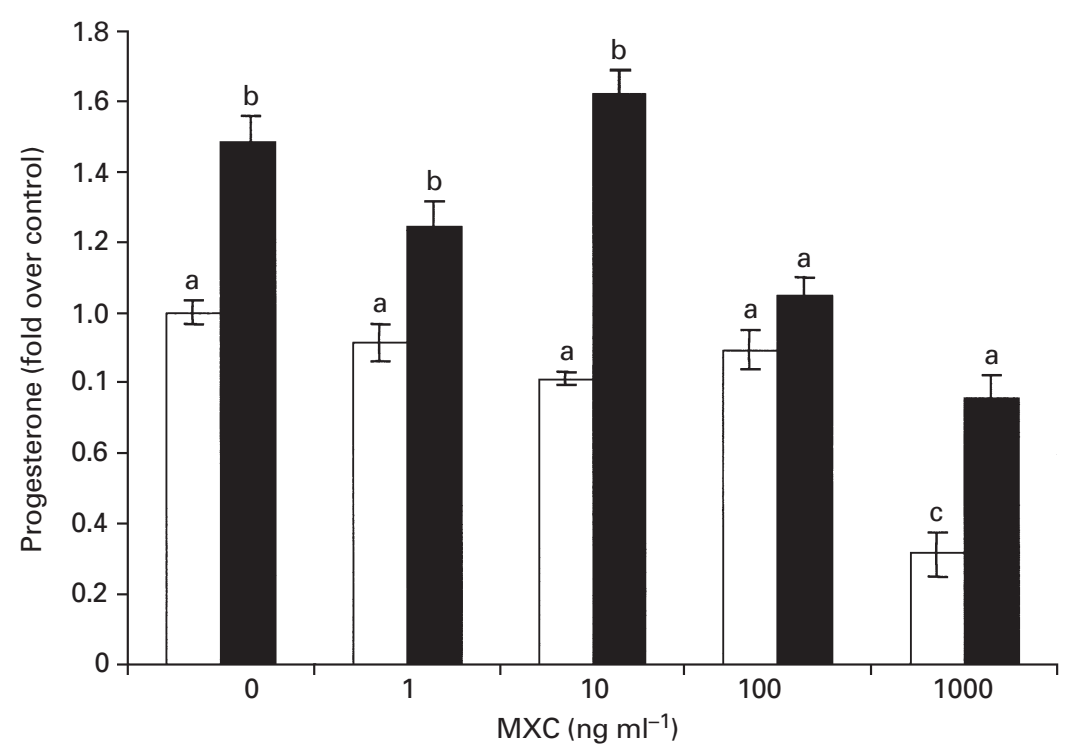

Fig. 2. Effect of methoxychlor (MXC) on cholera toxin-stimulated progesterone synthesis. Cells were cultured with 1-1000 ng methoxychlor $\mathrm{ml}^{-1}$ and with or without $100 \mathrm{ng}$ cholera toxin $\mathrm{ml}^{-1}$. After $24 \mathrm{~h}$ incubation, culture media and cells were collected for progesterone and protein assays, respectively. Data are the mean \pm SEM of three independent replications, expressed as fold values versus

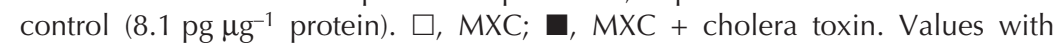
different letters are significantly different $(P<0.05)$.

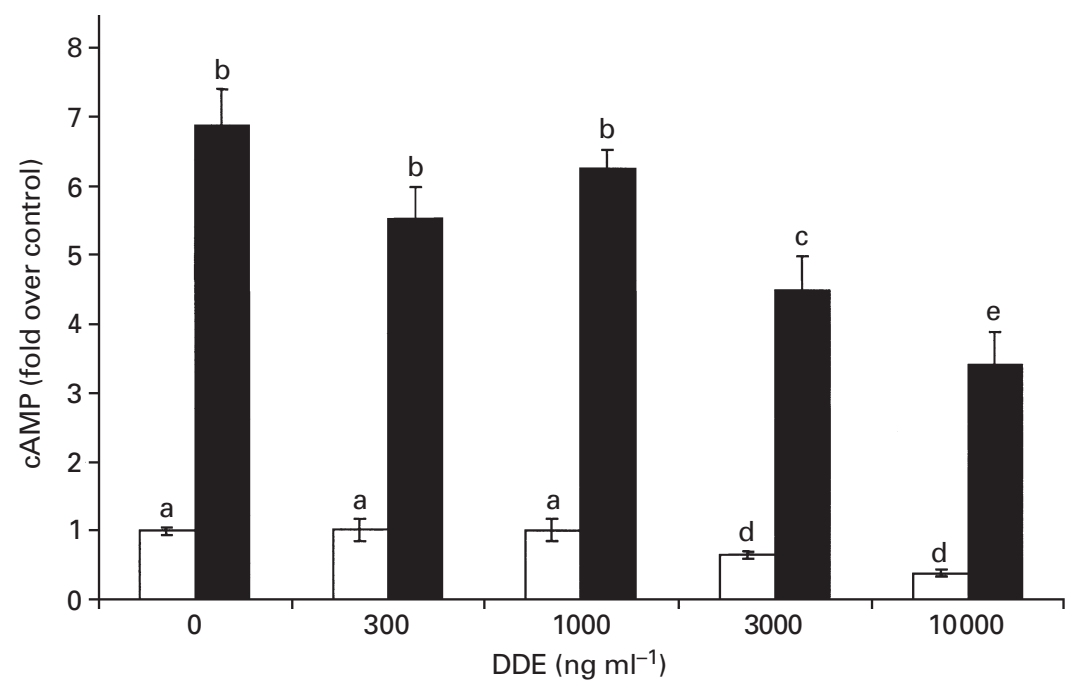

Fig. 3. Effect of dichlorodiphenyldichloroethylene (DDE) on cholera toxinstimulated cAMP synthesis. Cells were cultured with 300-10000 ng DDE ml-1 for $24 \mathrm{~h}$. Culture media was then replaced with culture media containing $125 \mu \mathrm{mol} 3$-isobutyl-1-methyl-xanthine (IBMX) $\mathrm{I}^{-1}$ and with or without $100 \mathrm{ng}$ cholera toxin $\mathrm{ml}^{-1}$. After 30 min incubation, cells were collected for cAMP assay. Data are the mean \pm SEM of three independent replications, expressed as fold

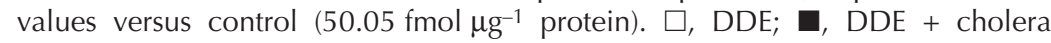
toxin. Values with different letters are significantly different $(P<0.05)$. 


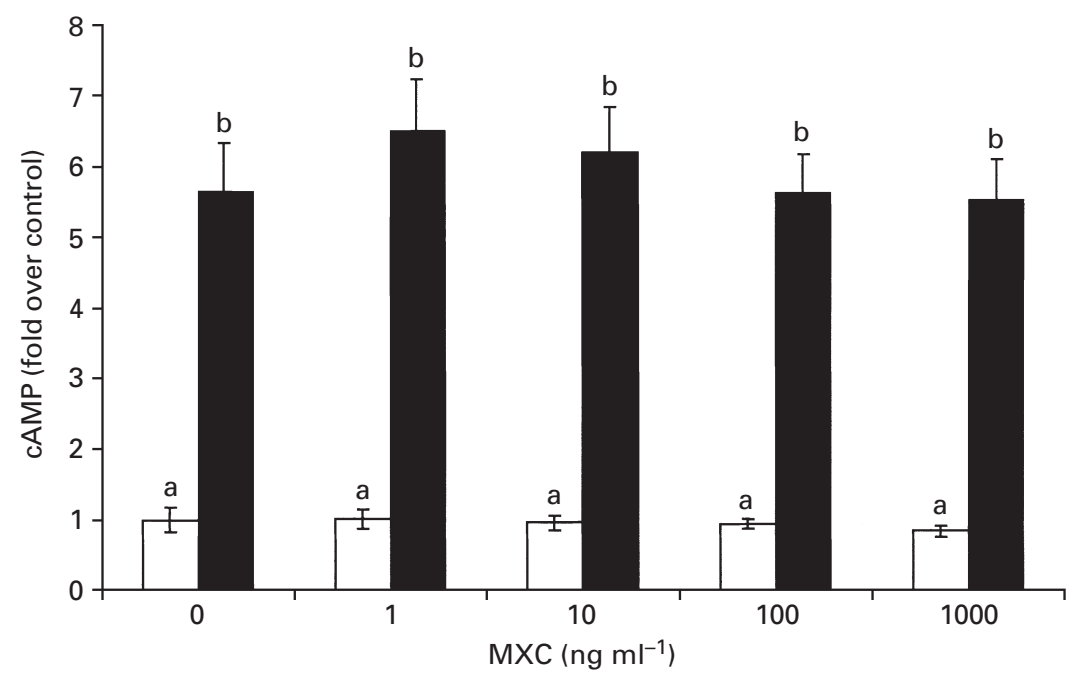

Fig. 4. Effect of methoxychlor (MXC) on cholera toxin-stimulated cAMP synthesis. Cells were cultured with 1-1000 ng methoxychlor $\mathrm{ml}^{-1}$ for $48 \mathrm{~h}$. Culture media were then replaced with culture media containing $125 \mu \mathrm{mol}$ 3-isobutyl-1-methyl-xanthine (IBMX) I $^{-1}$ with or without 100 ng cholera toxin $\mathrm{ml}^{-1}$. After $30 \mathrm{~min}$ incubation, cells were collected for cAMP assay. Data are the mean \pm SEM of three independent replications, expressed as fold values versus control (32.2 fmol $\mu \mathrm{g}^{-1}$ protein). $\square, \mathrm{MXC} ; \mathbf{\square}, \mathrm{MXC}+100 \mathrm{ng}$ cholera toxin $\mathrm{ml}^{-1}$. Values with different letters are significantly different $(P<0.05)$.

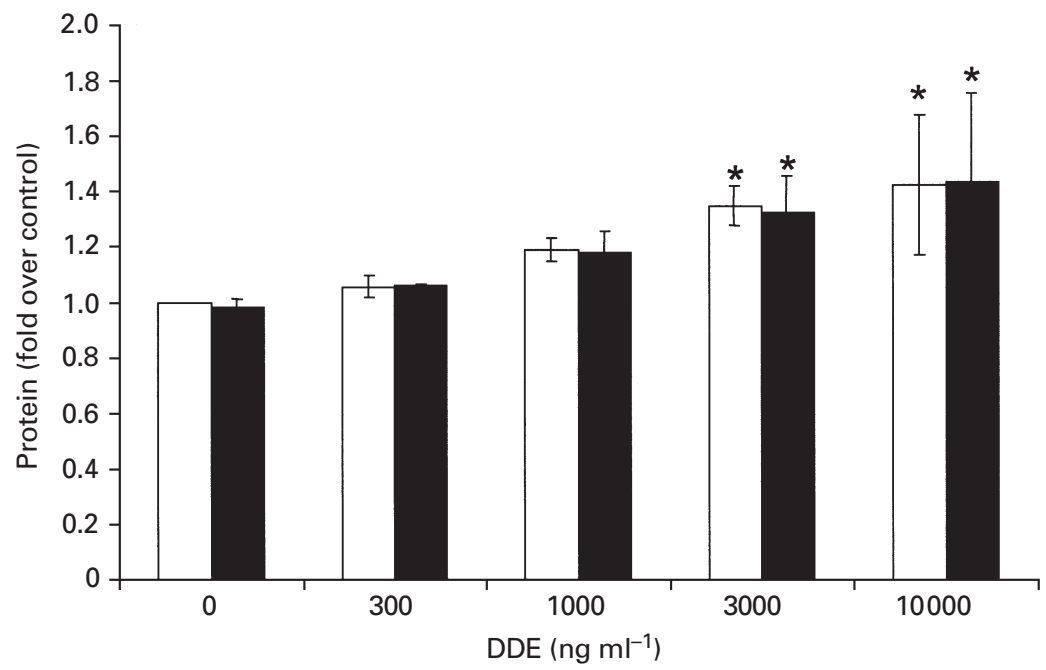

Fig. 5. Effect of dichlorodiphenyldichloroethylene (DDE) on protein content. Cells were cultured with 300-10000 ng DDE ml-1. After $24 \mathrm{~h}$ incubation, cells were collected for protein assay. Data are the mean \pm SEM of three independent replications, expressed as fold values versus control. $\square$, DDE; $\mathbf{\square}$, DDE + cholera toxin. Values with asterisks are significantly different from $(P<0.05)$ controls (30.8 $\mu \mathrm{g})$. 


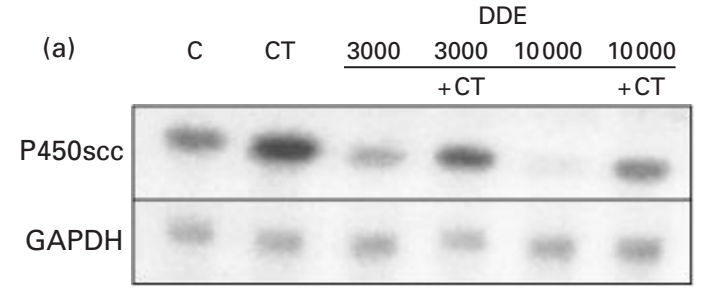

(b)

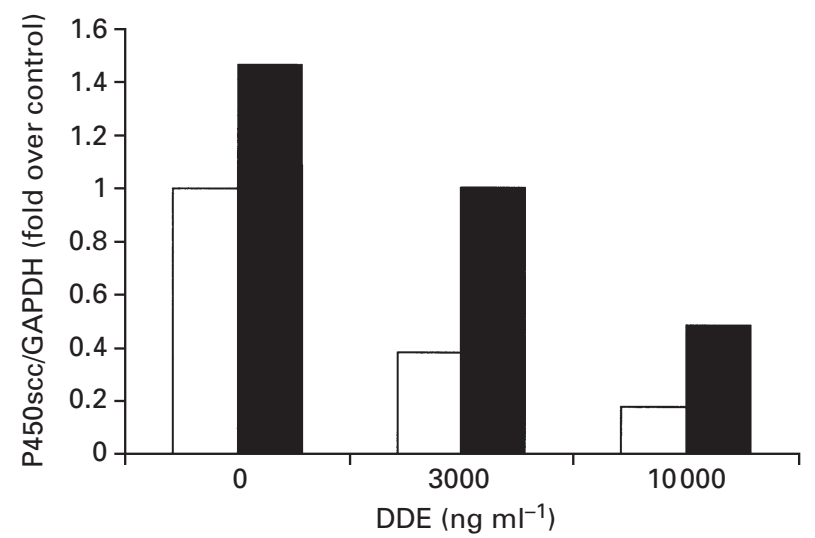

Fig. 6. Effect of dichlorodiphenyldichloroethylene (DDE) on cholera toxin (CT)-stimulated P450scc mRNA and glyceraldehyde-3-phosphate dehydrogenase (GAPDH) mRNA concentrations. Cells were cultured with 3000 or 10000 ng DDE $\mathrm{ml}^{-1}$ and with or without $100 \mathrm{ng}$ cholera toxin $\mathrm{ml}^{-1}$. After $24 \mathrm{~h}$ incubation, cells were collected for northern blot analysis. (a) Autoradiograph of a northern blot from a representative experiment. (b) Graph of the densitometric analysis data, expressed as fold values versus control. $\square, \mathrm{DDE} ; \mathbf{\square}, \mathrm{DDE}+$ cholera toxin.

P450scc mRNA was increased 3.48-fold after $48 \mathrm{~h}$ incubation., At 100 and $1000 \mathrm{ng} \mathrm{ml}^{-1}$, methoxychlor also increased P450scc mRNA 1.79- and 3.0-fold, and further increased cholera toxin-stimulated amounts of P450scc mRNA 6.47- and 5.44-fold, respectively (Fig. 7).

\section{Discussion}

The present study investigated the effect of DDE and methoxychlor on progesterone synthesis on a stable steroidogenic pig granulosa cell line, JC-410. The cells of this line do not respond to the gonadotrophins FSH and $\mathrm{LH}$, the physiological regulators of granulosa cell steroidogenesis. However, they do respond to cholera toxin, a protein kinase A (PKA) activator that mimics the effect of $\mathrm{FSH}$ on progesterone synthesis in granulosa cells.

Previous investigations have shown that low concentrations of DDE (10-100 $\left.\mathrm{ng} \mathrm{m}^{-1}\right)$ increase PKAstimulated progesterone synthesis after $24 \mathrm{~h}$ incubation (Crellin et al., 1999). This effect is mediated by an increase in the expression of the P450scc gene, which is considered to be a regulated step in progesterone synthesis

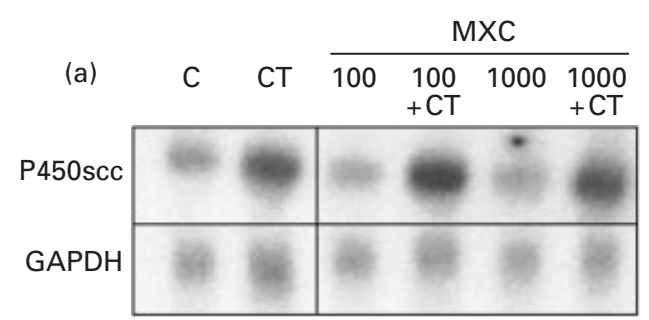

(b)

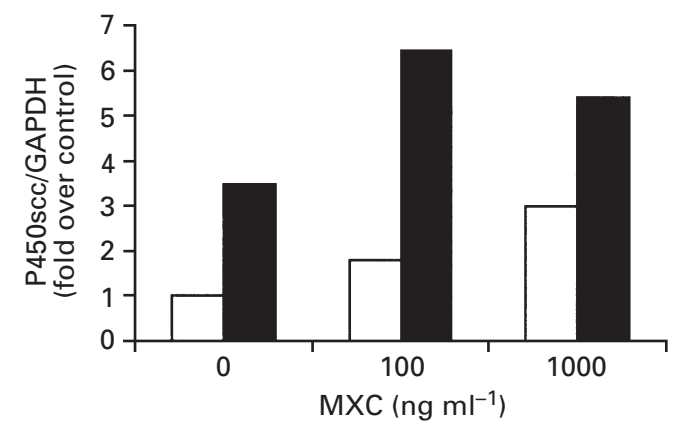

Fig. 7. Effect of methoxychlor (MXC) on cholera toxin (CT)stimulated P450scc mRNA and glyceraldehyde-3-phosphate dehydrogenase (GAPDH) mRNA concentrations. Cells were cultured with 100 or $1000 \mathrm{ng}$ methoxychlor $\mathrm{ml}^{-1}$ and with or without $100 \mathrm{ng}$ cholera toxin $\mathrm{ml}^{-1}$. After $24 \mathrm{~h}$ incubation, cells were collected for northern blot analysis. (a) Autoradiograph of a northern blot from a representative experiment. (b) Graph of the densitometric analysis data, expressed as fold values versus control. $\square$, MXC; $\mathbf{\square}, \mathrm{XXC}+$ cholera toxin.

(Richards, 1994). The results of the present study demonstrated that high concentrations of DDE (1000-10000 $\mathrm{ng} \mathrm{m}^{-1}$ ) decreased basal and cholera toxinstimulated progesterone synthesis and that DDE had a similar inhibitory effect on basal and cholera toxinstimulated CAMP generation. As the effect of cholera toxin on P450scc mRNA was completely blocked, while cAMP generation was decreased only to a small extent, it is possible that high concentrations of DDE also directly affect P450scc gene expression. Thus, the decrease in the expression of the P450scc gene is the consequence of the inhibitory effect of DDE on CAMP generation. From these results it is possible to conclude that DDE affects progesterone synthesis in granulosa cells through two different mechanisms. The first mechanism, observed with low concentrations of DDE, potentiates the effect of PKA activators on the expression of P450scc, resulting in an increase in the conversion of cholesterol to pregnenolone. The second mechanism, observed with high concentrations of DDE, impairs generation of CAMP.

Exposure to DDE also increased granulosa cell protein synthesis, an effect that was independent of PKA stimulation. In contrast, methoxychlor alone or in combination with cholera toxin did not affect protein synthesis. DDE has been described as a weak oestrogen, 
capable of binding and activating the oestrogen receptor (Coldham et al., 1997; Andersen et al., 1999) and also as an anti-androgen (Kelce et al., 1995). Although the presence of androgen receptors has not been demonstrated definitively in the JC-410 cells, secondary experimental evidence indicates that it is present (Rodway et al., 1999). It is also known that endogenous androgen or oestrogen synthesis does not occur in these cells. Thus, if androgens do stimulate cell proliferation, this may occur after their conversion into oestrogens, since JC-410 cells have an active aromatase system. Therefore, it is possible that

the increase in protein synthesis, observed in the present study, was the result of increased cellular proliferation induced by DDE. This result is in accordance with the reported oestrogenic effects of DDE observed in the oestrogen-responsive MCF-7 breast cancer cells (Soto et al., 1995). Hence, the inhibitory effect of DDE on steroidogenesis may be dissociated from its proliferative actions.

Although it is accepted that methoxychlor has antifertility effects, its mechanism of action has not yet been elucidated. In the present study, exposure to methoxychlor for $48 \mathrm{~h}$ inhibited progesterone synthesis in granulosa cells and this inhibitory effect is consistent with the observation that methoxychlor decreased serum progesterone concentrations in pregnant rats (Cummings and Laskey, 1993). Methoxychlor may affect progesterone synthesis by blocking a step in the steroidogenic pathway distal to CAMP generation, but before pregnenolone synthesis. Granulosa cells are surrounded by a basal membrane, which limits the entrance of lipoproteins into the follicular cavity. Consequently, cholesterol is mainly obtained from acetate in a reaction catalysed by HMGCoA reductase, which is a crucial step in granulosa cell steroidogenesis (Richards, 1994). The expression and activity of HMG CoA reductase in granulosa cells is under the control of FSH and oestradiol (Maitra et al., 1995; Di Croce et al., 1999). Steroid hormone synthesis also depends on the transport of cholesterol into the mitochondria, which is mediated by steroid acute regulatory protein (StAR)(Stocco and Clark, 1996). Therefore, it is possible that HMG-CoA reductase or StAR, or both, are potential targets for the endocrine disrupting activity of methoxychlor.

The effects of the gonadotrophins are mediated through mechanisms involving synthesis of cAMP and activation of PKA, which trigger a cascade of intracellular reactions leading to steroid synthesis. Concentrations of DDE or methoxychlor sufficient to block PKA-stimulated progesterone synthesis could reduce the effect of $\mathrm{FSH}$ by inhibiting its signal cascade and the steroidogenic pathway. $\mathrm{FSH}$ is crucial for the normal development of the ovarian follicle and for oocyte maturation. Therefore, an inhibitory effect of DDE and methoxychlor on FSH-induced steroidogenesis may result in a subtle but detrimental effect on granulosa cells, causing a higher number of anovulatory cycles and, consequently, affecting fertility.

The low concentrations of DDE used in a previous study (Crellin et al., 1999), which increased PKAstimulated progesterone synthesis, were in the range of concentrations reported to be contaminating human follicular fluid in a Canadian study (Jarrell et al., 1993). The higher concentrations of DDE used in the present study are in the range of the serum concentrations detected in populations exposed to high amounts of DDT (Lopez-Carrillo et al., 1997; Rivero-Rodriguez et al., 1997). Methoxychlor, although more degradable in the environment, may also cause toxicity by direct exposure. It is quite possible that differences in the potencies of DDE and methoxychlor may contribute to the different mechanisms of action in granulosa cells. The results of the present study indicate that both DDE and methoxychlor inhibit basal- and stimulated-progesterone synthesis in granulosa cells and that the normal effect of gonadotrophins may be hindered in individuals as a consequence of exposure to DDE or methoxychlor. Thus, both the presence of DDE in the environment and the use of methoxychlor may present a threat to the health and fertility of humans and domestic and wild animals.

This research was supported by grants from the Canadian Network of Toxicology Centres, Saskatchewan Health (Government of Saskatchewan), Medical Research Council of Canada, Natural Sciences and Engineering Research Council of Canada and College of Medicine, University of Saskatchewan (Clinical Teaching and Research Grant), to P. J. Chedrese. The authors thank Lauren and Eduardo Ansaldo for their critical review of the manuscript and Christine Meaden for editorial assistance.

\section{References}

Andersen HR, Andersson AM, Arnold SF, Autrup H, Barfoed M, Beresford NA, Bjerregaard P, Christiansen LB, Gissel B and Hummel R (1999) Comparison of short-term estrogenicity tests for identification of hormone-disrupting chemicals Environmental Health Perspectives 107 Supplement 1 89-108

Ayotte P, Dewailly E, Bruneau S, Careau H and Vezina A (1995) Arctic air pollution and human health: what effects should be expected? Science of the Total Environment 160-161 529-537

Chedrese PJ, Zhang D, Luu-The V, Labrie F, Juorio AV and Murphy BD

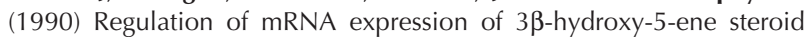
dehydrogenase in porcine granulosa cells in culture: a role for the protein kinase-C pathway Molecular Endocrinology 4 1532-1538

Chedrese P, Rodway M, Swan C and Gillio-Meina C (1998) Establishment of a stable steroidogenic porcine granulosa cell line Journal of Molecular Endocrinology 20 287-292

Chomczynski P and Sacchi N (1987) Single step method of RNA isolation by acid guanidinium thiocyanate-phenol-chloroform extraction Analytical Biochemistry 162 156-159

Coldham NG, Dave M, Sivapathasundaram S, McDonnell DP, Connor C and Sauer MJ (1997) Evaluation of a recombinant yeast cell estrogen screening assay Environmental Health Perspectives 105 734-742

Crellin NK, Rodway MR, Swan CL, Gillio-Meina C and Chedrese PJ (1999) Dichlorodiphenyldichloroethylene potentiates the effect of protein kinase A pathway activators on progesterone synthesis in cultured porcine granulosa cells Biology of Reproduction $\mathbf{6 1}$ 1099-1103

Cummings AM and Laskey J (1993) Effect of methoxychlor on ovarian steroidogenesis: role in early pregnancy loss Reproductive Toxicology 
7 17-23

Di Croce L, Guillermo PV, Pecci A, Bruscalupi G, Trentalance A and Beato M (1999) The promoter of the rat 3-hydroxy-3-methylglutaryl coenzyme A reductase gene contains a tissue-specific estrogenresponsive region Molecular Endocrinology 13 1225-1236

Eroschenko VP (1991) Ultrastructure of vagina and uterus in young mice after methoxychlor exposure Reproductive Toxicology 5 427-435

Eroschenko VP, Abuel-Atta AA and Grober MS (1995) Neonatal exposures to technical methoxychlor alters ovaries in adult mice Reproductive Toxicology 9 379-387

Fainberg AP and Vogelstein B (1983) A technique for radiolabelling DNA restriction endonuclease fragments to high specific activity Analytical Biochemistry 123 6-13

Guillette LJ, Jr, Gross TS, Grow DA, Rooney AA and Percival HF (1995) Gonadal steroidogenesis in vitro from juvenile alligators obtained from contaminated or control lakes Environmental Health Perspectives 103 $31-36$

Guillette LJ, Jr, Pickford DB, Crain AD, Rooney AA and Percival FH (1996) Reduction in penis size and plasma testosterone concentrations in juvenile alligators living in a contaminated environment General and Comparative Endocrinology $10132-42$

Jarrell JF, Villeneuve D, Franklin C, Bartlett S, Wrixon W, Kohut J and Zouves CG (1993) Contamination of human ovarian follicular fluid and serum by chlorinated organic compounds in three Canadian cities Canadian Medical Association Journal 148 1321-1327

Kelce WR, Stone CR, Laws SC, Gray LE, Demppainen JA and Wilson EM (1995) Persistent DDT metabolite $p, p^{\prime}-D D E$ is a potent androgen receptor antagonist Nature 375 581-584

Lopez-Carrillo L, Blair A, Lopez-Cervantes M, Cebrian M, Rueda C, Reyes R and Mohar A (1997) Dichlorodiphenyltrichloroetane serum levels and breast cancer risk: a case-control study from Mexico Cancer Research 57 3728-3732

Maitra A, LaVoie H, Day RN, Garmey JC and Veldhuis JD (1995) Regulation of porcine granulosa cell 3-hydroxy-3-methylglutaryl coenzyme A reductase by insulin and insulin-like growth factor I: synergism with follicle-stimulating hormone or protein kinase A agonist Endocrinology 136 5111-5117

Morgan D and Roan C (1971) Absorption, storage, and metabolic conversion of ingested DDT and DDT metabolites in man Archives of Environmental Health 22 301-308

Mulheron GW, Stone RT, Miller WL and Wise T (1989) Nucleotide sequence of cytochrome P450 cholesterol side chain cleavage cDNA isolated from porcine testis Nucleic Acid Research 1741773

Pickford DB and Morris ID (1999) Effects of endocrine-disrupting contaminants on amphibian oogenesis: methoxychlor inhibits progesterone-induced maturation of Xenopus laevis oocytes Environmental Health Perspectives 107 285-292

Richards J (1994) Hormonal control of gene expression in the ovary Endocrine Reviews 15 725-751

Rivero-Rodriguez L, Borja-Aburto VH, Santos-Burgoa C, Walixzewsky S, Rios C and Cruz V (1997) Exposure assessment for workers applying DDT to control malaria in Veracruz, Mexico Environmental Health Perspectives 105 98-101

Rodway MR, Swan CL, Crellin NK, Gillio-Meina C and Chedrese PJ (1999) Steroid regulation of progesterone synthesis in a stable porcine granulosa cell line: a role for progestins Journal of Steroid Biochemistry and Molecular Biology 68 173-180

Soto AM, Sonnenschein C, Chung KL, Fernandez MF, Olea N and Olea Serrano F (1995) The E-SCREEN assay as a tool to identify estrogens: an update on estrogenic environmental pollutants Environmental Health Perspectives 103 Supplement 7 113-122

Steel R and Torrie J (1980) Principles and Procedures of Statistics, a Biometrical Approach McGraw-Hill, New York

Stocco DM and Clark BJ (1996) Regulation of the acute production of steroids in steroidogenic cells Endocrine Reviews 17 221- 44

Tso JY, Sun X-H, Kao T-H, Reece KS and Wu R (1985) Isolation and characterization of rat and human glyceraldehyde-3-phosphate dehydrogenase cDNAs: genomic complexity and molecular evolution of the gene Nucleic Acids Research 13 2485-2502

Resubmitted manuscript received 12 July 2000. Accepted 16 October 2000. 